\title{
Decorative grown malachite. Nature and technology
}

\author{
T. G. Petrov ${ }^{1}$, E. N. Protopopov ${ }^{2}$, and A. V. Shuyskiy ${ }^{1}$ \\ Received 1 August 2013; accepted 13 August 2013; published 20 August 2013.
}

The history of creation of industrial technology jewelry and semi-precious malachite and its main features were briefly described. Malachite produced by JENAVI (St. Petersburg, Russia) is identical to the natural in all of its physical, chemical, structural, decorative and performance properties. The peculiarities of the obtained material were discussed. The advantages of getting malachite at the factory are: nature conservation, production safety, the adjustability of the pattern, almost complete wastelessness and lower cost compared to the natural one. Photographs of grown malachite products are included. KEYWORDS: Grown malachite; malachite synthesis method; three chamber crystallizer; jewelry.

Citation: Petrov, T. G., E. N. Protopopov, and A. V. Shuyskiy (2013), Decorative grown malachite. Nature and technology, Russ. J. Earth. Sci., 13, ES2001, doi:10.2205/2013ES000529.

\section{Introduction}

Natural malachite which can be usually found in the oxidation zone of copper deposits is microcrystalline druse $\mathrm{Cu}_{2}\left[\mathrm{CO}_{3}\right](\mathrm{OH})_{2}$ or, in other words, alkaline copper carbonate. Its hardness is low (3.5-4.0 on the Mohs scale), but it has relatively high density $\left(3.9-4.1 \mathrm{~g} / \mathrm{cm}^{3}\right)$. The characteristics mentioned above may vary due to the impurities contained in it. Green colour, an almost infinite variety of patterns, relative ease of processing - this set of characteristics assured success of malachite as a material for women's jewelry, small statuary and interior appearance elements in large halls [Semyonov, 1987]. The fact that industry had been concentrated mostly on technologically important materials delayed the development of the method of its laboratory and factory production, despite the fact that people have been interested in it since the prehistoric times.

The attempts to synthesize this beautiful stone have been made many times. The first work dedicated to malachite synthesis was published in 1799 by Proust [Leicester and Klickstein, 1952 Proust, 1799. While disclosing one of the stoichiometry laws (the law of constant proportion), he got it in the form of powder. In 1835, Becquerel got malachite as fine needle-shaped crystals [Becquerel, 1835]. In the second half of the 19th century A. Schulten was involved in the malachite synthesis. He used a variety of methods which led to the formation of crusts, small crystals, powders, but he failed to synthesize dense material suitable for jewelry making [Chirvinskiy, 1903].

\footnotetext{
${ }^{1}$ Saint-Petersburg State University, Saint-Petersburg, Russia

${ }^{2}$ JENAVI Co., Saint-Petersburg, Russia
}

Copyright 2013 by the Geophysical Center RAS.

http://elpub.wdcb.ru/journals/rjes/doi/2013ES000529.html
On the whole, the attempts to synthesize malachite can be classified into three types of methods:

1. The majority of researchers were trying to imitate the natural conditions of malachite formation and created supersaturation by chemical synthesis reactions of the type: $2 \mathrm{CuO}+\mathrm{CO}_{2}+\mathrm{H}_{2} \mathrm{O}=\mathrm{Cu}_{2} \mathrm{CO}_{3}(\mathrm{OH})_{2}$.

2. Electrochemical reactions of malachite crusts deposition at the anode [Chirvinskiy, 1903 .

3. Powder recrystallization which led to certain coarsening of grains (an extract in solution at elevated temperature) followed by formation of powdery mass units having no pattern [Doelter, 1912 Mellor, 1928 Petrov, 1987 .

In 1936-1937 the mineralogist N. M. Salov who was consulted by Professor D. P. Grigoriev managed to get a tight fusion of malachite microcrystals, but it didn't have the necessary ornamental qualities [Kulikov, 2000].

In 1974 in the University of Connecticut F. Ruszala and E. Kostiner got malachite monocrystals up to $1.5 \mathrm{~mm}$ in size by means of chemical synthesis in hydrothermal conditions $\left(250-310^{\circ} \mathrm{C}, 3.5 \mathrm{kbar}\right)$ using the reaction of copper sulfate and sodium hydrogen carbonate [Ruszala and Kostiner, 1974. Alcaline copper carbonate powder called malachite also could be used as catalysts for which patents exist, however, it is not relevant to our topic.

In the early 70-es T. G. Petrov and A. E. Glikin in the Research Institute of the Earth Crust in the Leningrad State University (LSU) started to work on the malachite synthesis. In $1973 \mathrm{~S}$. V. Moshkin joined the research and for a long time was taking part in the further development of the industrial method [Petrov, 1987]. On May, 30, 1975 an application for an inventor's certificate was filed on behalf of the Research Institute of the Earth Crust in the LSU, and 
it was received in 1977 under the number 102486. Through the offices of A. V. Nardov the method was soon introduced at the Sverdlovsk plant "Ural gems" [Filatov, 2006, Shuyskiy and Petrov, 2011.

Soon the work on malachite synthesis started in the city of Alexandrov in Russian Research Institute of Mineral Resources Synthesis (VNIISIMS) and Institute of Experimental Mineralogy (IEM) of USSR Academy of Sciences under the direction of V. S. Balytsky. These organizations synthesized grown malachite in 1981, and it was found out that it had much in common with natural malachite [Mel'nikov and Chernenko, 2003a, 2003b.

Malachite was synthesized in Sverdlovsk at the "Ural Gems" plant with the use of Research Institute of the Earth Crust technology for several years. A bit later the production started in Saint-Petersburg in the firm called "Sever" which operated until the mid-nineties. After that malachite was produced by the Saint-Petersburg firm called "Jenavi" where it has been produced until present moment. Now the work on improving of the equipment for malachite synthesis and on improving of technological process reproductivity is held there. Apart from "Jenavi" no other firm produces malachite which means that other methods of synthesis were not applied industrially.

The authors have not any information concerning malachite synthesis abroad.

\section{Natural Malachite as a Standard}

Beautiful unique collection of photos of natural malachite as samples and products is given in a two-volume book [Semyonov, 1987. You can usually find natural malachite in the form of layers and masses with nodular surface, often with a radiating structure and concentrically zoned pattern which can be seen after splitting or cutting. The malachite colour is green, but it can vary from almost white to practically black depending mostly on the grain size, which gets darker during its growth. With few exceptions, when crystal aggregates are formed, malachite is a dense fusion of needle-shaped crystals which are usually not thicker than a few hundredths of a millimeter. The single - grown from one center - malachite crystal aggregate which is formed in natural conditions has a ball shape, or, in other words, is a spherulite. Spherulites form different crystalline materials. The common requirement of their formation is large relative supersaturation resulting in crystal cleavage followed by geometric selection [Punin and Shtukenberg, 2008], which leads to a radial arrangement of crystals.

Malachite is formed from the solutions flowing down uneven surfaces of cracks and caverns. Supersaturation fluctuations cause colour changing of the growing layer. The combination of these factors stipulates the great variety of malachite patterns. Undulation usually appears which is stipulated by the uneven surface where the layer growing took place. In section regular rings which are parallel the total surface area growth can be seen. These are the spherulites separate sections. In the sections which are parallel to the

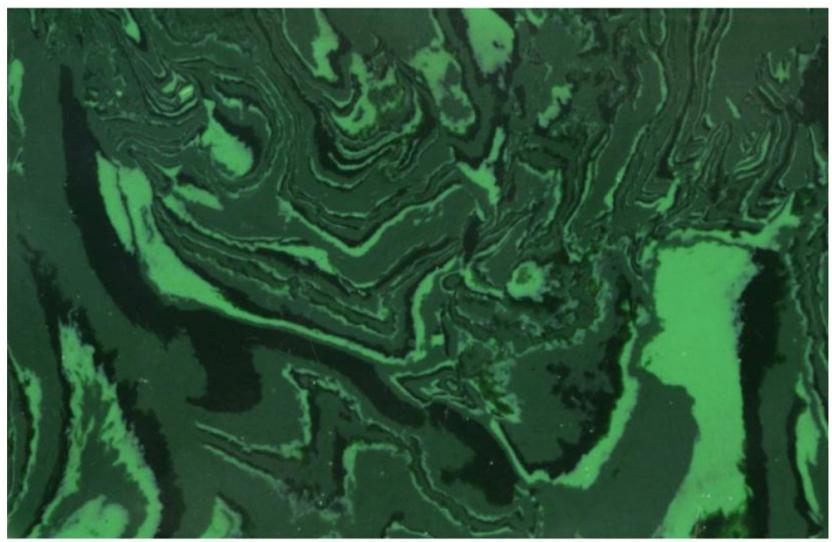

Figure 1. Malachite imitation. Size: $7 \times 10 \mathrm{~cm}$

growth direction the polarity is manifested in the direction of spherulitic sectors expansion.

"Plush" is one of the key features of malachite. It is characterized by the colour intensity changes depending on the sample, light sourse and eye position (see details below). At high supersaturation microspherolitic malachite is formed. It is not characterised by "plush" and correspondingly doesn't change the colour depending on the cut direction. The colour of such malachite is always bright: the smaller the crystals in the aggragate are, the lighter the colour is.

People try to make imitations of the malachite patterns. There are quite a lot of them, however, we would like to draw your attention to one of them which has flooded the gemstones market. In small items it can be quite difficult to distinguish it by eye, however in larger items, lumps and plates it can be seen at a glance. First of all, areas of the same colour dramatically vary in thickness and their relations are chaotic. Secondly, there are only three shades of green in the pattern. Thirdly, there is no "plush" which is a common feature of all imitations (Figure 1.

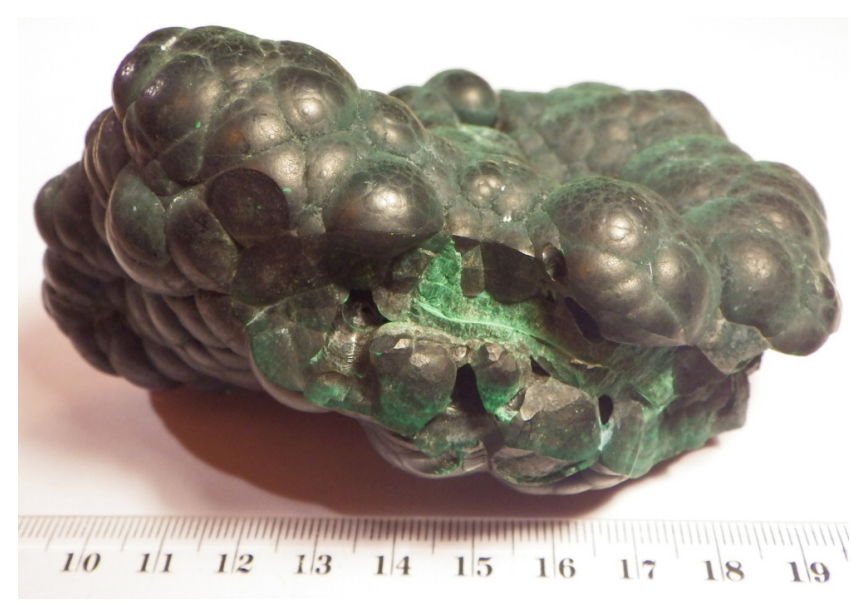

Figure 2. Grown malachite with clearly seen incrustive nodular surface of growing. Photo by V. V. Udovichenko. 


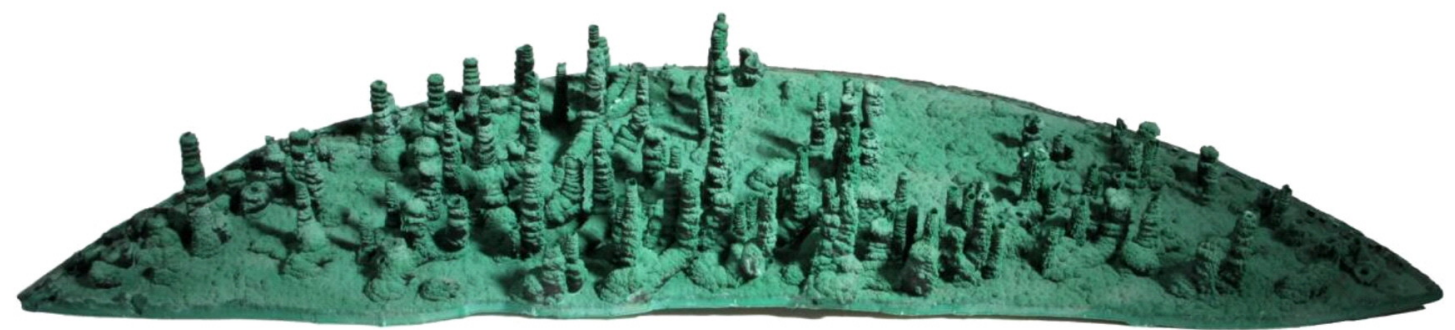

Figure 3. Grown malachite with "amphorae" (width $\sim 30 \mathrm{~cm}$ )

\section{Production Method}

According to the method developed by the Research Institute of the Earth Crust in LSU the crystallization of waterammonia solutions takes place. Three-chamber crystallization van works by recycling with the solvent transfer in the gas phase. The lower chamber is used for crystallization with heated floor. The middle chamber contains starting material (reagent $\mathrm{CuCO}_{3} \mathrm{Cu}(\mathrm{OH})_{2}$ and waste products), the upper chamber operates as a condenser of vapors rising from the crystallization chamber through an axial tube [Petrov et al., 1983 Protopopov et al., 2000. The temperature in the crystallization chamber is maintained at $60-80^{\circ} \mathrm{C}$. The growth of the material in the form of thick layer takes place on the walls and at the bottom of the crystallization chamber and on substrates of different shapes. During the technological cycle which lasts for 2 months the material growth forms a $10 \mathrm{~mm}$ layer on the surface. The growth takes place on the uneven surface for the pattern enrichment. Incrustive nodular surface is typical for both grown and natural malachite Figure 2.

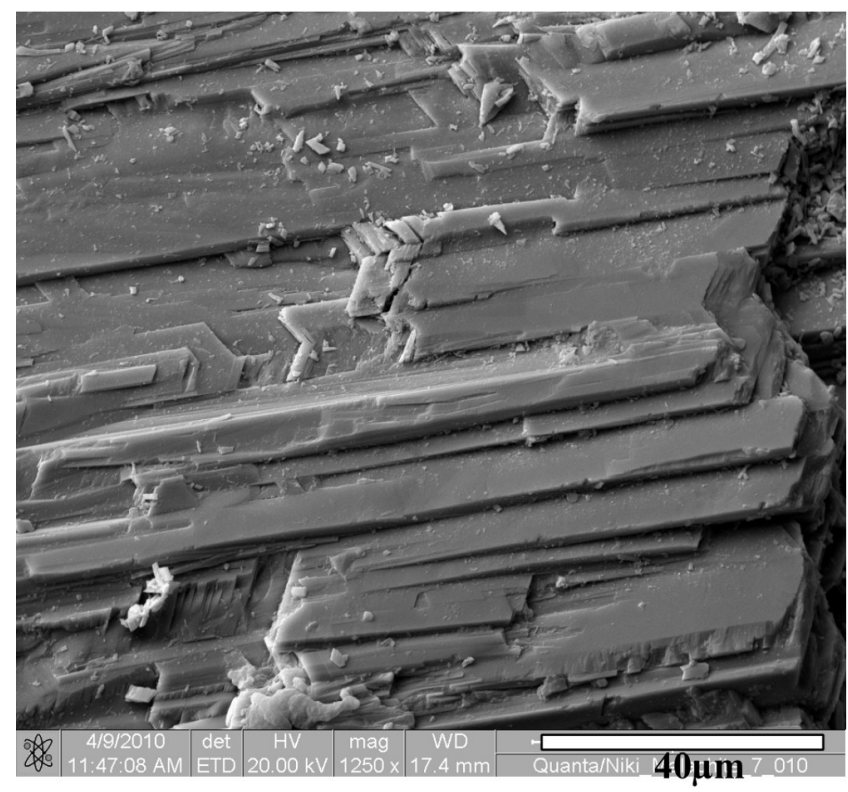

Figure 4. Grown thin-needle malachite cleavage which is parallel to the growth direction.
This is a manifestation of unequal development of spherulites with a vivid manifestation of "plush" when cutting, splitting. During the growing on a thread cylindrites with concentric-zonal structure appear. The process of malachite formation is rather sensitive to the temperature changes which is used for colour changing, appearing of stripes which are parallel to the growth surface. If you exceed the rated speed of crystallization, the gas bubbles appear on the bottom surface. They give rise to formation of tubes - "amphorae" which reduce the product yield (Figure 3) [Shuyskiy, 2007.

Properties of malachite as gemstone material are determined by the structural and crystallographic characteristics of malachite and by the conditions of its production. Under constant conditions of the spherulite growth splitting provides nearly constant thickness of the needle-shaped crystals. With the decrease of supersaturation and the slowdown in splitting process crystal thickness increases. If the growth takes place on flat surface, a layer of needle-shaped crystals with quasi-parallel arrangement appears (Figure 4). The layer is characterized by the microknobby surface (Figure 5). Knobbles are the heads of single crystals which were formed

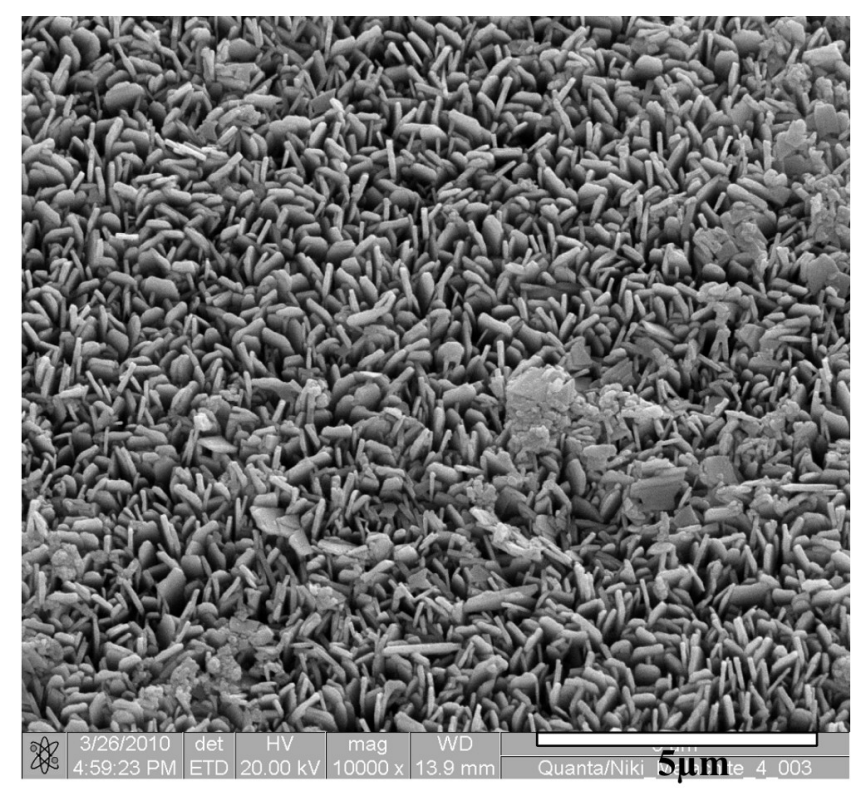

Figure 5. Malachite growth surface. The crystal heads can be seen. 


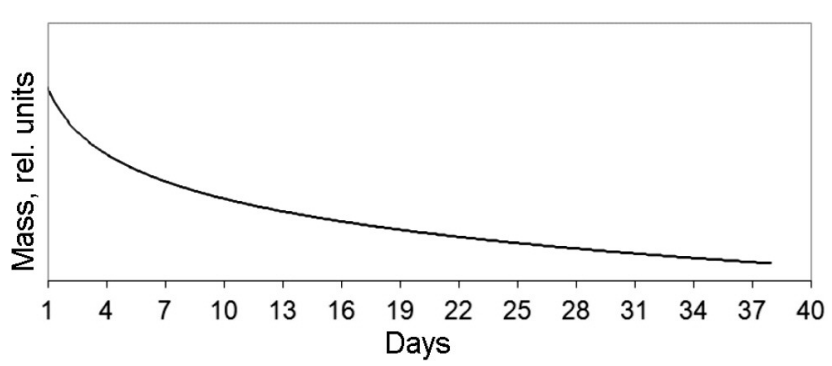

Figure 6. Weight loss during drying.

during the last stage of growth at low supersaturation.

The material extracted from the crystallization van contains some solution between the crystals and therefore has certain blue shade. Moreover, its hardness is lowered. The latter is due to the constant competition for the space between growing crystals. This causes stiffening in the material. In some forms the problem of supporter stiffening can be solved by the formation of cracks. Drying of the material is conducted at the temperature of $35-40^{\circ} \mathrm{C}$. The dependence of weight loss to time is shown in the Figure 6 During drying the removal (evaporation) of the solvent and crystallization of the rest part of the solution go on simultaneously with recrystallization. It also contributes to the hardness increasing due to reducing stiffening by mass transfer from areas with the maximum stiffening to the areas where stiffening is lower. During drying the material weight loss is from 0.5 to $1 \%$.

The identity of grown and natural malachite has been repeatedly tested by a variety of methods [Bublikova et al., 2000 Domnina and Filatov, 1986, Mel'nikov and Chernenko, 2003a 2003b Petrov et al., 1986. It is necessary to mention that the diffraction data of the obtained material correspond to the standards of natural malachite mentioned in the International Centre for Diffraction Data ICDD PDF-2 [Kaminskaya, 1999], and the infrared spectra of grown malachite coincide with those of the natural malachite [Shuyskiy and Zorina, 2013.

\section{Grown Malachite as Jewelry and Ornamental Material and Products Thereof}

Grown malachite is characterized by higher resistance and polishability due to its higher purity in comparison with natural malachite.

During manufacturing process in "Jenavi" firm the plates of bottom malachite are cut into plates, thickness of which is $1 \mathrm{~mm}$ or more. The orientation of the cut surface to the plate surface is important for pattern revealing. The clearest pattern with maximum contrast is achieved when the cut is parallel to the growth direction. With the increasing of the cut deviation to the surface from the norm the contrast weakens and if the plane of the growth is parallel, the material is usually characterized by almost black colour.

The material which has grown on the wall of the crys-

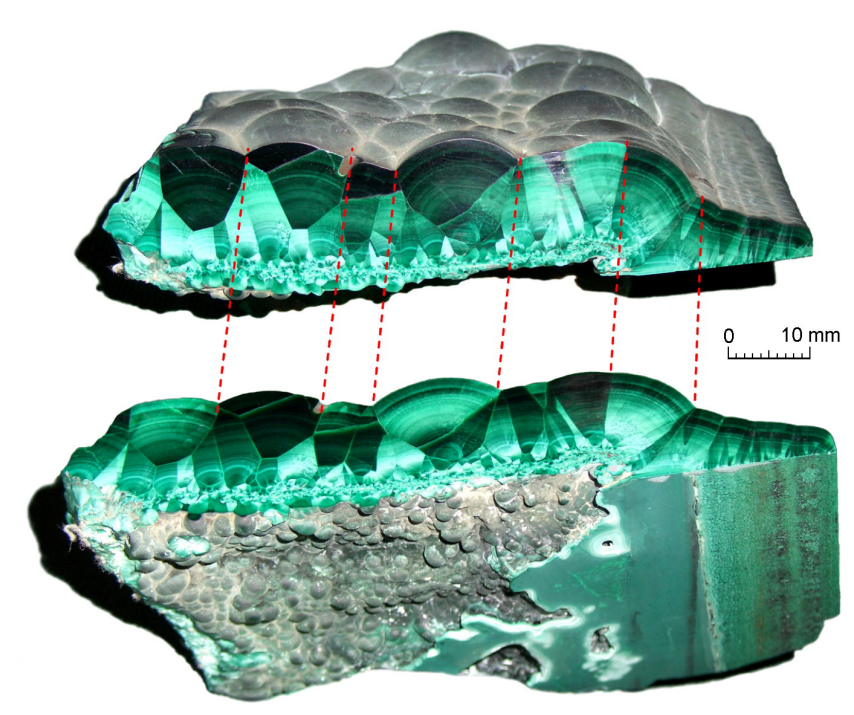

Figure 7. "Plush" malachite. The same sample in different positions. The colour variations of the same surface areas can be seen.

tallization chamber is characterized by more diverse pattern than the bottom material. Its preservation after a reboot and removal of bottom material allows growing the wall layer up to $40-50 \mathrm{~mm}$. The "plush" mentioned above can be clearly seen in this material (Figure 7). The reasons of its appearance are the following. When the beam passes through the diameter of thin crystals - needles - and is reflected from their back side, light green colour can be seen. The beam caught in the needle face passes along them as if a needle is a beam waveguide and is absorbed with almost no reflection, that is why the colour is practically black [Petrov, 1987. In other words, the more light is reflected from the near-surface layer of the material, the lighter it is. This means that "plush" is stronger or weaker (or there may be no "plush" at all) depending on the cut (cleavage) position to the growth direction and the angle between the item, eye and the light source.

The pattern of grown malachite is very diverse when supporters are used or crystallization conditions vary. This means that it can be used for manufacturing of all types of products in which traditionally natural malachite is used. In Figure 8 you can see fine products and in Figure 9- an ashtray, a jewel-case and a cigarette-case, inlaid with grown malachite. A chandelier is depicted in Figure 10

In 2008 the work which allows treating grown malachite as a potential material for restoration of historic monuments was carried out. The example of malachite decoration of the main iconostasis of St. Isaac's Cathedral in Saint-Petersburg clearly shows that grown malachite can make up the shortcomings in the iconostasis without ruining the integrity of the pattern and its colours (http://www.isaac.spb.ru/reading/y2009/shuisky. [Shuyskiy and Petrov, 2008]). 

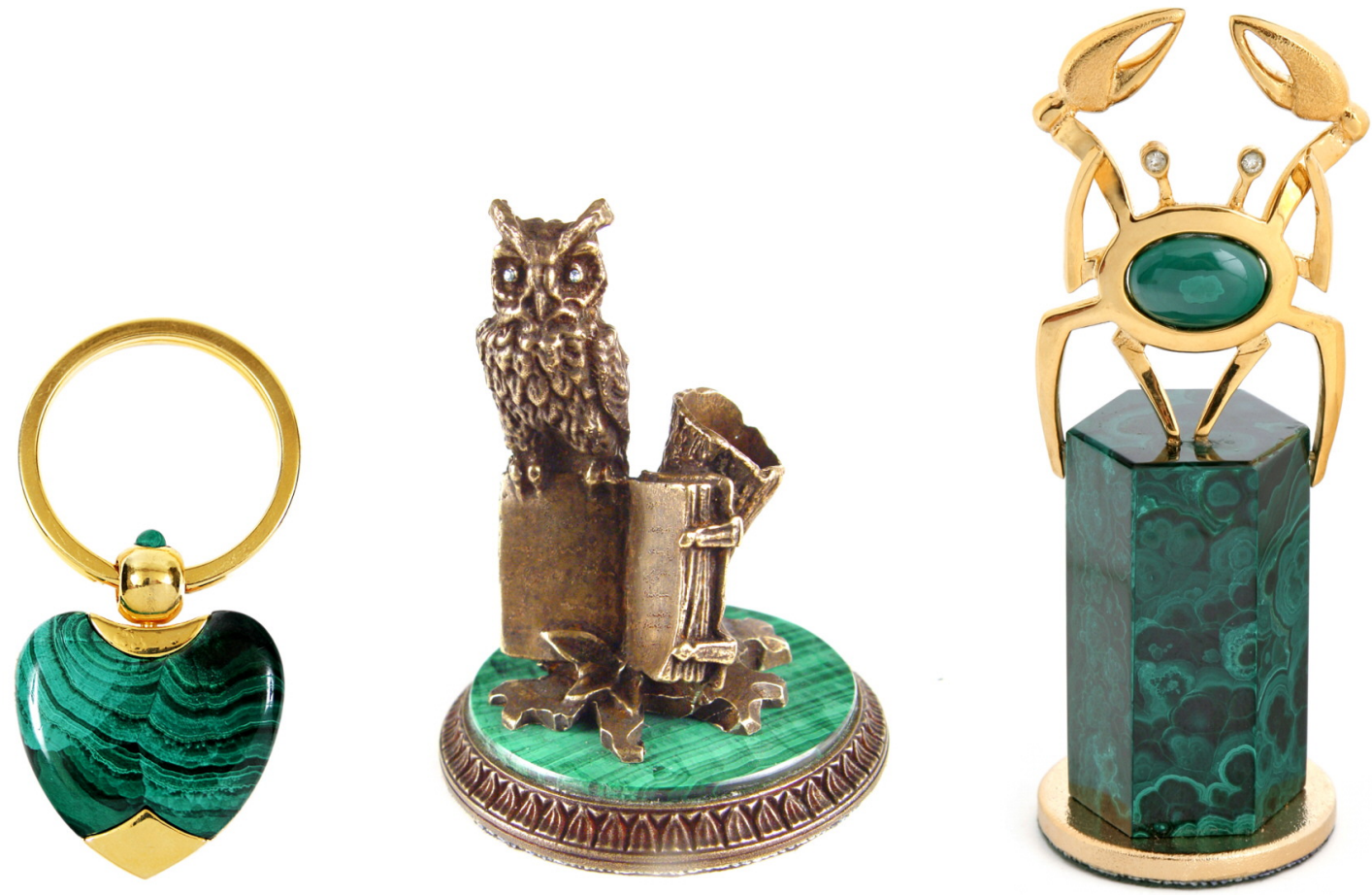

Figure 8. Products with grown malachite. Keychain (brass, gilding). Desk tidy (bronze, copper plating). Astrological sign, cancer (bronze, gilding). Actual size.

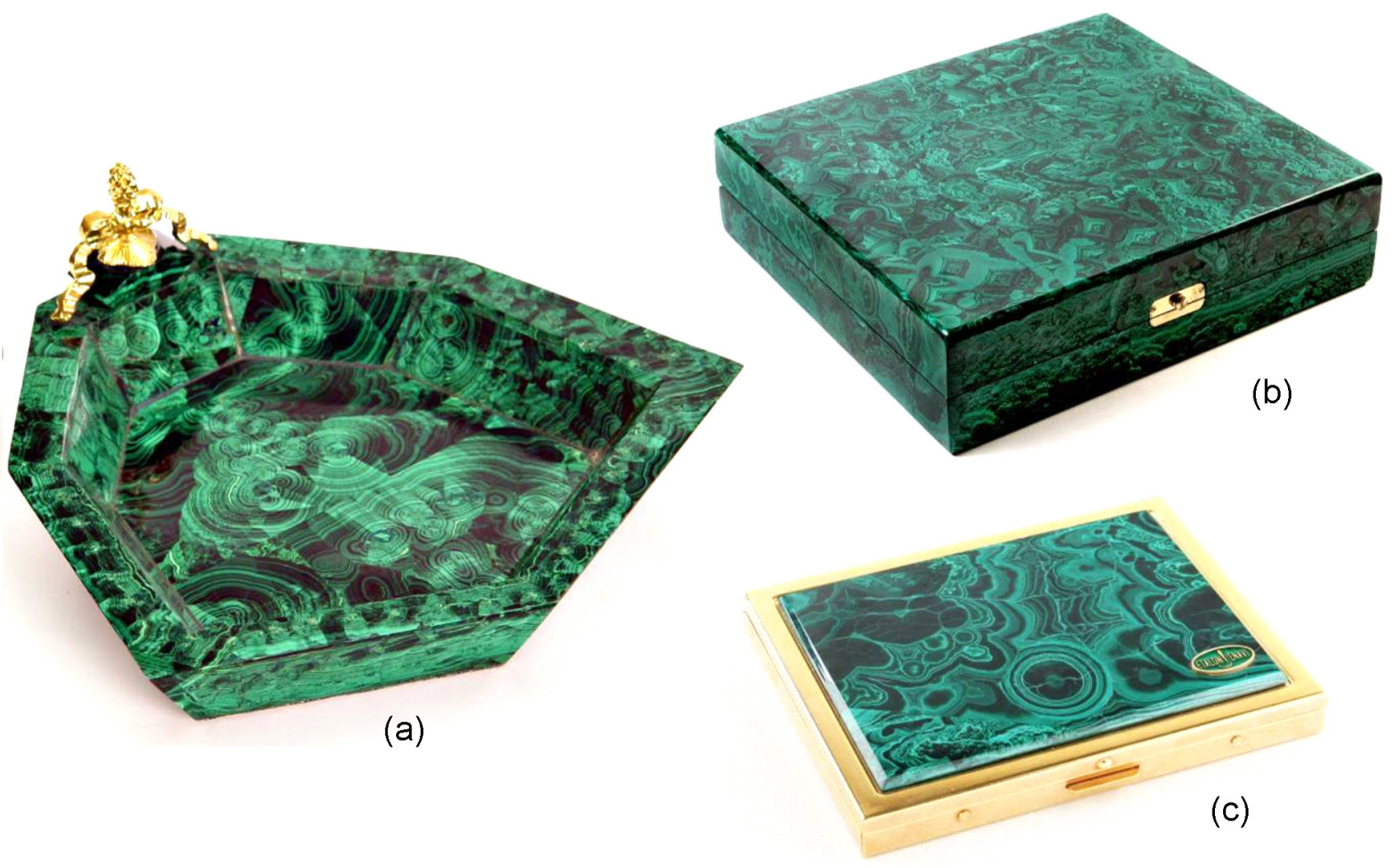

Figure 9. (a) Ashtray. Inlay (bronze, gilding). Height $35 \mathrm{~mm}$, width $130 \mathrm{~mm}$. (b) Jewel-case. $320 \times$ $320 \times 90 \mathrm{~mm}$. (c) Cigarette-case (steel, gilding). $100 \times 60 \mathrm{~mm}$. 

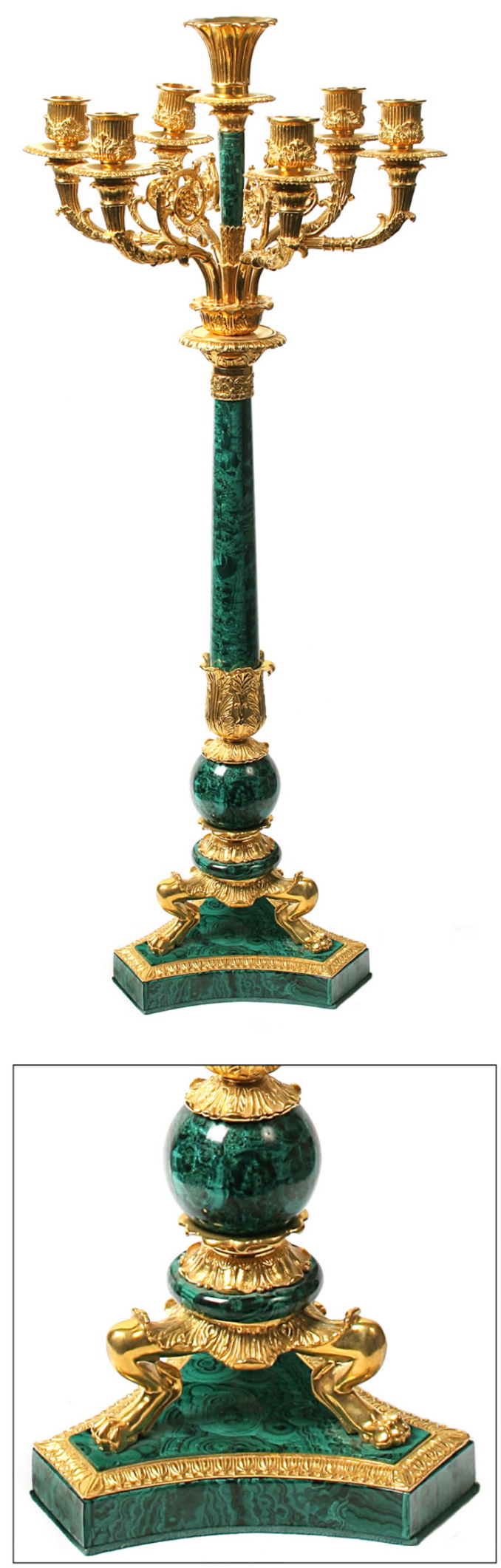

Figure 10. Chandelier (bronze, gilding). Height $1.25 \mathrm{~m}$.

\section{Conclusion}

Taking into consideration well-known difficulties connected with mining industry, such as danger to the miners' lives, hazards of underground work, dependence of extraction on the deposit geology peculiarities and the total depletion of non-renewable natural resources, including malachite, the development of production method for products which are not coming out of fashion can be treated not only as a scientific and technological but also as a cultural achievement.

As for the present technology of malachite production, it is necessary to mention that so far it is impossible to constantly produce light "non-plush" malachite. Grown malachite can be always characterized by a certain degree of "plush" which slightly limits the opportunities for the artist. The disadvantage of the material is blue shade of some of its types, though it is generally light, which is not typical for natural malachite. However, natural malachite of this colour shade also exists if there are phosphate impurities in it.

On the whole, the method of malachite plant manufacturing is significantly better than natural malachite mining. Besides, grown and natural malachite are almost indistinguishable. Malachite synthesis is safe, when production is properly organized, harmless and less time-consuming in comparison with mining. It is possible to plan the scopes of the material produced and also set its pattern. The production is non-waste, and due to everything mentioned above the resulting cost of grown malachite is much lower than the cost of natural malachite.

\section{References}

Becquerel, M. C. (1835), Sur les moyens de produire a l'aide de forces electriques tres faibles, de la malachite sembable a celle que l'on trouve dans la nature, Comptesrendus Hebdomadaires des Sances de l'Academie des Siences, Vol. I, Paris, Bachelier, Imprimeur-libraire, 19.

Bublikova, T. M., V. C. Balitskiy, I. V. Timohina (2000), Sintez i osnovnie svoystva yuvelirno-podelochnogo malahita, Synthez Mineralov, Vol. 1, Aleksandrov, 502-532.

Chirvinskiy, P. N. (1903), Iskusstvennoe Poluchenie Mineralov v XIX Stoletii, Kiev, 406.

Doelter, C. (1912), Handbuch der Mineralchemie, Bd. 1. Dresden and Leipzig: Verlag von Theodor Steinkopff.

Domnina, M. I., S. K. Filatov (1986), Termicheskie deformacii i psevdosloistost' malahita, Neorganicheskie Materiali, 22, 6, 984-989.

Filatov, S. K. (2006), Perviy Virashchenniy Malahit, SanktPeterburgskiy Universitet, 22(3745), 51-54.

Kaminskaya, T. N. (1999), Zacluchenie po Rezul'tatam Issledovaniya Obraztcov Prirodnogo i Sinteticheskogo Malahita.

Kulikov, B. F. (2000), Slovar'-Spravochnik Kamney-Samocvetov, Moskva, 128-130.

Leicester, H. M., H. S. Klickstein (1952), A Source Book of Chemistry 1400-1900, New York, McGraw-Hill, 202.

Mellor, J. W. A. (1928), Comprehensive Treatise Inorganic and Theoretical Chemistry, vol. III, London, Longmans, 270.

Mel'nikov, E. P., T. V. Chernenko (2003a), Svoystva i diagnostika prirodnogo i sinteticheskogo malahita, Vestnyk Gemmologii, 8, $11-26$.

Mel'nikov, E. P., T. V. Chernenko (2003b), Svoystva i diagnostika 
prirodnogo i sinteticheskogo malahita, Vestnyk Gemmologii, 9, $31-35$.

Petrov, T. G. (1987), Kristallogeneticheskoe Modelirovanie Processov Mineraloobrazovaniya: Dissertaciya, Leningrad, 304352.

Petrov, T. G., S. V. Moshkin, V. Yu. Zhogoleva (1986), Sravnitel'noe izuchenie morfologicheskih i fiziko-himicheskih harakteristik sinteticheskogo i prirodnogo malahita, Trudy Leningradskogo Obshchestva Estestvoispytateley, Vol. 79, Vip. 2, 142151

Petrov, T. G., E. B. Treyvus, Yu. O. Punin, A. P. Kasatkin (1983), Vyrashchivanie Kristallov iz Rastvorov, Leningrad, 200. Proust, J. L. ( 1799), Ann. Chim. 32, 26-54.

Protopopov, E. N., V. S. Protopopova, V. V. Sokolov, T. G.Petrov, S. V. Moshkin, A. V. Nardov (2000), Sinteticheskiy Yuvelirno-Podelochniy Malahit $i$ Sposob ego Polucheniya, Patent Rossiyskoy Federatcii RU2159214.

Punin, Yu. O., A. G. Shtukenberg (2008), Avtodeformatcionnie Defekty Kristallov, Saint-Petersburg, 318.

Ruszala, F., E. Kostiner (1974), The hydrothermal synthesis of single crystals of azurite and malachite, Journal of Crystal Growth, 26, 1, 155-156, doi 10.1016/0022-0248(74)90219-X
Semyonov, V. B. (1987), Malahit, 2 volumes, Sverdlovsk.

Shuyskiy, A. V. (2007), Genezis trubchatih obrazovaniy v estestvennom i virashchennom malahite, Tezisy II Mezhdunarodnoy Konferentcii "Kristallogenezis i Mineralogiya", SanktPeterburg, 145-148.

Shuyskiy, A. V., T. G. Petrov (2008), Malahit v ubranstve Isaakievskogo sobora i vyrashchivaemiy malahit kak material dlya restavratcii, Kafedra IV. Materialy nauchnoprakticheskoy konferentcii "Isaakievskiy Sobor Mezhdu Proshlym i Budushchim", Sankt-Peterburg, 268-286.

Shuyskiy, A. V., T. G. Petrov (2011), Istoriya polucheniya malahita, Problemy Mineralogii, Petrografii $i$ Metallogenii, Vip. 14, Nauchnie chteniya pamyati P. N. Chirvinskogo, Perm', 64-71.

Shuyskiy, A. V., M. L. Zorina (2013), Infrakrasnie spektry prirodnogo i virashchennogo malahita, Zhurnal Pricladnoy Spektroskopii, 80, 4 (in print).

T. G. Petrov, and A. V. Shuyskiy, Saint-Petersburg State University, Saint-Petersburg, Russia (alexshuyskiy@gmail.com)

E. N. Protopopov, JENAVI Co., Saint-Petersburg, Russia 